Bulgarian Academy of Sciences. Space Research and Technology Institute.

Aerospace Research in Bulgaria. 31, 2019, Sofia

DOI: https://doi.org/10.3897/arb.v31.e13

\title{
MODEL OF THE OPERATOR FOR CONTROLLING THE AIRCRAFT WITH MATHEMATICAL MODELLING OF THE MOVEMENT
}

\author{
Ognyan Stoykov \\ Aviation Faculty, National Military University, Bulgaria \\ e-mail: oss_10@abv.bg
}

the operator

Keywords: Aircraft, Mathematical modelling, Linear model, Transmitting function of

Abstract

For controlling the aircraft with mathematical modelling of its movement in case of aiming at surface targets is proposed the use of the transmitting function of the operator, which is in itself a linear model in a tracking mode.

\section{Introduction}

For mathematical modelling of the movement of the aircraft aiming at surface targets is used the transmitting function of the operator.

The operator monitors the target (angles $\beta_{1 \mathrm{~T}}, \varepsilon_{1 \mathrm{~T})}$ and the moving grid on a screen and observing the position of the target relative to the targeting grid, i.e. the differences $\beta_{1}-\beta_{1 \mathrm{~T}}$ and $\varepsilon_{1}-\varepsilon_{1 \mathrm{~T}}$, attempts to eliminate them utilizing the controls of the aircraft. The aircraft reacting to the deflection of the controls changes the parameters of its position relative to the target [1,3, and 5].

\section{Main body}

In order to obtain the model of the aforementioned process, it is necessary to model the reaction of the operator to the mismatching, i.e. to obtain the calculated values of the aircraft controls deflection depending on the angles of mismatching:

$$
\begin{aligned}
& \delta_{\text {ви }}=\delta_{\text {ви }}\left(\varepsilon_{1}-\varepsilon_{1 \mathrm{~T}}\right) ; \\
& \delta_{\text {еи }}=\delta_{\text {еи }}\left(\beta_{1}-\beta_{1 \mathrm{~T}}\right),
\end{aligned}
$$

where $\delta_{\text {ви }}, \delta_{\text {еи }}$ are the calculated values of deflection of the elevators and ailerons (the angle of the rudder $\delta_{\mathrm{H}}=0$ ) 
The role of the operator as a control unit of the closed system pilot-aircraft consists in:

- obtaining information from the onboard instruments and the environment;

- processing the obtained information and determining the amount of force that needs to be applied on the aircraft controls;

- applying the necessary amount of force on the controls of the aircraft.

The model of control of the aircraft, with participation of the operator, works based on the principle "tracking with pursuit" or tracking with compensation. In the system pilot-operator, the operator observing the quantity of the input and output signal of the system attempts to reduce to minimum the mismatching between the target and the tracking grid $[2,4]$.

To adequately describe the work of the operator in the control system, their transmitting function (or another mathematical definition) has to reflect the main characteristics of the operator as a operator are:

- ability to part of the control system. The main characteristics of the

- temporary delay of their reaction by the input signal;

- ability to adapt to the dynamic characteristics of the object of control and the character of the input signal impact;

- ability to react to deviations of the parameter from the predefined quantity, to its derivative and the integral of the deviation from parameter;

- intensify the quantity of the force applied on the controls;

- non-linearity of the operator's characteristics;

- functioning of the operator within the control system as a multi-channel unit; potential.

- dependency of the quality of operator's control upon their psycho-energetic

There are various models (linear, non-linear) in existence that describe the work of the operator, including the abovementioned characteristics. The linear models, which are the most convenient from an engineering point of view, have been developed in details and have been widely applied. These, however, possess certain disadvantages:

- they do not consider to a sufficient degree the ability of the operator to forestall the process;

- they are not capable of explaining the experimental data which indicate that in some occasions the operator manifests discreet behavior.

With a linear model of the operator in tracking mode, they are regarded as a unit of the tracking system and can be described with transmitting function. It is assumed that the transmitting functions of all the operators possess identical structures and their individual characteristics are given an account of through the values of the coefficients of the transmitting functions. The model of the operator 
provides not an accurate but an approximate account of the characteristics of the real operator.

To obtain the calculated values of aircraft's controls deflection depending on the angles of mismatching

$$
\delta_{\text {ви }}=\delta_{\text {ви }}\left(\varepsilon_{1}-\varepsilon_{1 \mathrm{~T}}\right), \delta_{\text {еи }}=\delta_{\text {еи }}\left(\beta_{1}-\beta_{1 \mathrm{~T}}\right) \text {, }
$$

the following transmitting function of the operator is proposed:

$$
\mathrm{W}_{\text {л }}(\mathrm{p})=\frac{\mathrm{K}_{0} \mathrm{e}^{-\tau \mathrm{p}}\left(\mathrm{T}_{1} \mathrm{p}+1\right) \mathrm{K}_{1}}{\left(\mathrm{~T}_{2} \mathrm{p}+1\right)\left(\mathrm{T}_{3} \mathrm{p}+1\right)},
$$

where $\tau$ is the time characterizing the delay of the reaction to the input signal;

- $K_{0}$ - coefficient of intensification of the operator;

- $\mathrm{T}_{1}$ - constant coefficient, characterizing the ability of the operator to differentiate, i.e. to react to the speed of change of the input signal;

- $\mathrm{T}_{2}$ - constant coefficient of the inertial (aperiodic) unit of the operator;

- $\mathrm{T}_{3}$ - constant coefficient defining the neuro-shoulder reaction;

- $K_{1}$ coefficient of intensification of the neuro-shoulder unit.

The structural scheme of the preliminary function of the operator is illustrated on Fig. 1.

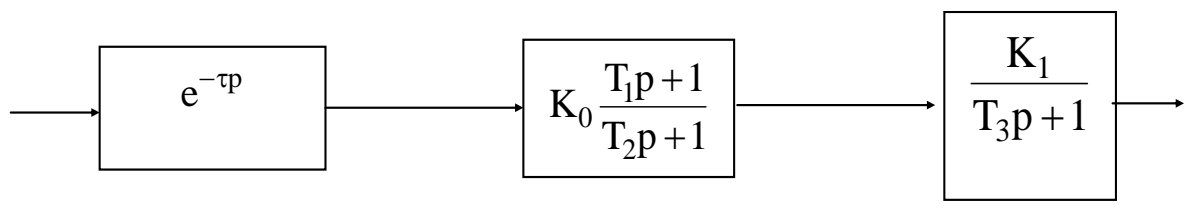

Fig. 1. Structural scheme of the transmitting function of the operator

The first unit responsible for receiving data from the instruments and processing the signals, in its dynamic characteristics is an intensifying unit with a delay function.

The second unit is a calculating element, performing intensification and differentiation of the received signals - it possesses the characteristics of intensifying, inertial and boosting units.

The third unit according to its dynamic characteristics is inertial and reflects the neuro-muscular influence on the object of control. Experiments show that the operator changes their transmitting characteristics depending on the quantities of the controlled object and the type of the functions of the interference. Experience, training and fatigue influence the type of the transmitting characteristics, i.e. the 
operator does not possess a certain, defined transmitting function but they can "tune" for work in accordance with any given function of a certain class.

For a certain type of tasks and specific aircraft the values of the coefficient of intensification $K_{0}$ and $K_{1}$ and the constant coefficients $T_{1}, T_{2}$, and $T_{3}$ and $\tau$ vary in small range.

The transmitting function of the operator is used to calculate the angles of deflection of the controls of the aircraft when mismatching signals are fed to it.

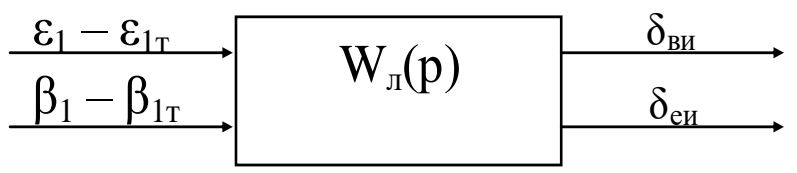

Fig. 2. Transmitting function of the operator members

Using the Taylor series and restricting it to the use of only the first two

$$
\mathrm{e}^{-\tau \mathrm{p}}=1-\tau \mathrm{p}
$$

and introducing the symbols:

$$
\begin{aligned}
& \varepsilon_{1}-\varepsilon_{1 \mathrm{~T}}=\varepsilon_{11} ; \\
& \beta_{1}-\beta_{1 \mathrm{~T}}=\beta_{11},
\end{aligned}
$$

we obtain:

$$
\begin{gathered}
\frac{\delta_{\text {ви }}}{\varepsilon_{11}}=-\frac{\mathrm{K}_{\mathrm{c.B}}\left(\mathrm{T}_{1} \mathrm{p}+1\right)(1-\tau \mathrm{p})}{\left(\mathrm{T}_{2} \mathrm{p}+1\right)\left(\mathrm{T}_{3} \mathrm{p}+1\right)} ; \\
\frac{\delta_{\text {ве }}}{\beta_{11}}=\frac{\mathrm{K}_{\mathrm{c.e}}\left(\mathrm{T}_{1} \mathrm{p}+1\right)(1-\tau \mathrm{p})}{\left(\mathrm{T}_{2} \mathrm{p}+1\right)\left(\mathrm{T}_{3} \mathrm{p}+1\right)},
\end{gathered}
$$

where $K_{c}=K_{0} K_{1}$ is the summary coefficient of intensification.

The higher the value of $\mathrm{T}_{1}$ is, the more difficult the control process becomes for the operator. Moreover, the necessary intensification of $T_{1}$ requires greater precision in determining the speed of change of the input signal of the operator.

With a proficient enough operator the transient process fades faster, if the following values of the quantitates $\tau, T_{1}, T_{2}$, and $T_{3}$ are adopted:

$$
\tau=0.1 \mathrm{~s}, \mathrm{~T}_{1}=0.1 \mathrm{~s}, \mathrm{~T}_{2}=0.1 \mathrm{~s}, \mathrm{~T}_{3}=0.1 \mathrm{~s} .
$$


From formulas (5), (6) and taking into consideration (7) are obtained the following differential equations for the longitudinal and lateral channel of control:

$$
\begin{aligned}
& \text { (8) } \ddot{\delta}_{\text {ви }}+20 \dot{\delta}_{\text {ви }}+100 \delta_{\text {ви }}=-\ddot{\varepsilon}_{11} \mathrm{~K}_{\text {св }}+100 \varepsilon_{11} \mathrm{~K}_{\text {св }} . \\
& \text { (9) } \ddot{\delta}_{\text {еи }}+20 \dot{\delta}_{\text {еи }}+100 \delta_{\text {еи }}=\ddot{\beta}_{11} \mathrm{~K}_{\text {се }}-100 \beta_{11} \mathrm{~K}_{\text {се }} .
\end{aligned}
$$

Introducing the symbol:

$$
\mathrm{z}_{1}=\dot{\delta}_{\text {ви }}+20 \delta_{\text {ви }}+\mathrm{K}_{\mathrm{cв}} \dot{\varepsilon}_{11},
$$

after differentiation we obtain:

$$
\dot{\mathrm{z}}_{1}=\ddot{\delta}_{\text {ви }}+20 \dot{\delta}_{\text {ви }}+\mathrm{K}_{\mathrm{cв}} \ddot{\varepsilon}_{11} \text {. }
$$

Then from equations (8) is obtained:

$$
\dot{\mathrm{z}}_{1}=100 \mathrm{~K}_{\mathrm{cв}} \varepsilon_{11}-100 \delta_{\text {ви }} \text {. }
$$

Introducing the symbol:

$$
\dot{\mathrm{z}}_{2}=\dot{\delta}_{\text {ви }}+\mathrm{K}_{\mathrm{cв}} \dot{\varepsilon}_{11} \text {, }
$$

from formula (10) is obtained:

(14) $\dot{\mathrm{z}}_{2}=\mathrm{z}_{1}-20 \delta_{\text {ви }}$.

From formula (13) it can be written:

$$
\dot{\delta}_{\text {ви }}=\dot{\mathrm{z}}_{2}-\mathrm{K}_{\mathrm{cв}} \dot{\varepsilon}_{11} \text {. }
$$

After integrating with zero input conditions:

$$
\delta_{\text {ви }}=\mathrm{z}_{2}-\mathrm{K}_{\text {св }} \varepsilon_{11} \text {. }
$$

And, finally, from equation (8) is obtained the system:

$$
\begin{aligned}
& \delta_{\text {ви }}=\mathrm{z}_{2}-\mathrm{K}_{\mathrm{cв}} \varepsilon_{11} ; \\
& \dot{\mathrm{z}}_{2}=\mathrm{z}_{1}-20 \delta_{\text {ви }} ; \\
& \dot{\mathrm{z}}_{1}=100 \mathrm{~K}_{\mathrm{cв}} \varepsilon_{11}-100 \delta_{\text {ви }} .
\end{aligned}
$$

Analogically, from equation (9) is obtained: 


$$
\begin{aligned}
& \delta_{\text {еи }}=\mathrm{z}_{4}+\mathrm{K}_{\text {се }} \beta_{11} ; \\
& \dot{\mathrm{z}}_{4}=\mathrm{z}_{3}-20 \delta_{\text {еи }} ; \\
& \dot{\mathrm{z}}_{3}=-100 \kappa_{\text {се }} \beta_{11}-100 \delta_{\text {еи }} .
\end{aligned}
$$

As a result of the integration of these equations are obtained the angles, required for control of the aircraft:

$$
\begin{aligned}
& \delta_{\text {в }}=\delta_{\text {ви }}+\delta_{\text {в.бал; }} \\
& \delta_{\mathrm{e}}=\delta_{\text {еи }},
\end{aligned}
$$

where: $\delta_{\text {ви, }}, \delta_{\text {еи }}$ are the values of the angles of the elevator and the ailerons, calculated using the transmitting function of the operator;

$\delta_{\text {в.бал }}-$ the balanced value of the angle of deflection of the rudder.

\section{Conclusion}

The problem of mathematical modeling of the movement of an aircraft with the use of the transmitting function of the operator consist in determining the summary coefficients of intensification $\mathrm{K}_{\mathrm{cB}}$, $\mathrm{K}_{\mathrm{ce}}$ based on the minimal time of fading of the preceding process using the accepted values of the quantities $T_{1}, T_{2}, T_{3}, \tau$ and known symbols in the transmitting function for the longitudinal and lateral channels of control.

\section{References}

1. Atanasov, M. A. and S. Mitev. Tochnost na opredeljane na koordinatite na v"zduhoplavatelno sredstvo po sposoba na doplerovoto opredeljane na p"tnata skorost, In: Nauchna konferencija „100 g. ot rozhdenieto na k-n Dimit"r Spisarevski“, NVU, fakultet “Aviacionen”, 2016, pp. 41-45, ISBN 978-954-713109-5, 2018. (in Bulgarian)

2. Atanasov, M. A. Algorit"m na rabota na aviacionen pricelen kompleks s"s sledjashta sistema pri bombopuskane, In: Sb. ot dokladi na NK ,S"vremenni tendencii v aviacionnoto obuchenie“, NVU, fakultet „Aviacionen“ NVU, 2017, pp. 114-121, ISBN 978-954-713-110-1 (in Bulgarian)

3. Atanasov, M. A., Modelirane na procesa na pricelvane s aviacionen pricelen kompleks s"s sledjashta sistema pri bombopuskane. In: Sb. ot dokladi na NK „S"vremenni tendencii v aviacionnoto obuchenie“, NVU, fakultet „Aviacionen“, 2017, pp. 121127, ISBN 978-954-713-110-1 (in Bulgarian)

4. Stojkov, S. O., Analiz na v"zmozhnostite na metodite za prinuditelno otdeljane na aviacionni bombi. In: Sb. ot dokladi na NK ,S"vremenni tendencii v aviacionnoto obuchenie“", NVU, fakultet “Aviacionen”, 2017, 56-60, ISBN 978-954-713-710-1

5. Stojkov, S. O., Analiz na bojnite v"zmozhnosti na iztrebitelite, JuNK, Tom I. NVU "V. Levski”, fakultet “Aviacionen”, D.M., 2013, pp. 85-89, ISBN 978-954-753-177-2 (Vol. 1). (in Bulgarian) 
МОДЕЛ НА ОПЕРАТОРА ЗА УПРАВЛЕНИЕ

НА ЛЕТАТЕЛНИЯ АПАРАТ ПРИ МАТЕМАТИЧЕСКО МОДЕЛИРАНЕ НА ДВИЖЕНИЕТО

\section{О. Стойков}

\section{Резюме}

За управление на летателния апарат при математическо моделиране на неговото движение с прицелване по земни цели се предлага използване на предавателната функция на оператора, представляваща линеен модел в режим на следене. 